\title{
Modeling studies of antarctic krill Euphausia superba survival during transport across the Scotia Sea
}

\author{
Bettina A. Fach ${ }^{1, *}$, Eileen E. Hofmann ${ }^{1}$, Eugene J. Murphy ${ }^{2}$ \\ ${ }^{1}$ Center for Coastal Physical Oceanography, Old Dominion University, Crittenton Hall, Norfolk, Virginia 23529, USA \\ ${ }^{2}$ British Antarctic Survey, Natural Environment Research Council, High Cross, Madingley Road, Cambridge CB3 0ET, \\ United Kingdom
}

\begin{abstract}
Antarctic krill Euphausia superba spawned on the outer continental shelf of the west Antarctic Peninsula can be entrained into the Southern Front of the Antarctic Circumpolar Current and transported across the Scotia Sea to South Georgia. A time-dependent, size-structured, physiologically based krill growth model was used to assess the food resources that are needed to sustain Antarctic krill during transport across the Scotia Sea and to allow them to grow to a size observed at South Georgia. Initial Lagrangian simulations provide trajectories that are followed by particles released on the west Antarctic Peninsula shelf. Pelagic phytoplankton concentrations along these trajectories are extracted from historical Coastal Zone Color Scanner measurements from the Antarctic Peninsula-Scotia Sea region and are input to the growth model. The results of these simulations show that pelagic phytoplankton concentrations are not sufficient to support continuous growth of Antarctic krill during the 140 to $160 \mathrm{~d}$ needed for transport to South Georgia. The inclusion of a supplemental

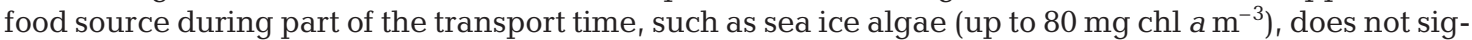
nificantly alter this result. Survival and growth of larval krill during modeled transport is, however, enhanced by encounters with mesoscale patches of high chlorophyll concentrations $\left(1 \mathrm{mg} \mathrm{m}^{-3}\right)$, while subadults and adults benefit less from these conditions. Further simulations show the importance of an additional food source, such as heterotrophic food, for the survival of subadult and adult Antarctic krill. For all planktonic food scenarios tested, krill that begin transport at the Antarctic Peninsula did not reach the smallest age group often observed at South Georgia, the 2+ group, during the 140 to $160 \mathrm{~d}$ of transport. Including the effect of increasing temperature across the Scotia Sea on krill growth rate does not significantly alter these results, since the maximum increase in growth due to increased temperature obtained in the simulations was $1.0 \mathrm{~mm}$ for both 2 and $22 \mathrm{~mm}$ Antarcic krill. These simulations suggest the possibility of alternative transport scenarios, such as Antarctic krill beginning transport at the Antarctic Peninsula in austral summer and overwintering under the sea ice that extends northward from the Weddell Sea into the Scotia Sea. Such an interrupted transport would allow the Antarctic krill to overwinter in a potentially better food environment and begin transport again the following year, growing to a size that is within the range observed for Antarctic krill populations at South Georgia.
\end{abstract}

KEY WORDS: Antarctic krill · Euphausia superba $\cdot$ Scotia Sea $\cdot$ Lagrangian model · Food limitation

\section{INTRODUCTION}

The waters around South Georgia, to the east of the Scotia Sea (Fig. 1), contain large populations of Antarctic krill Euphausia superba, the primary food for many

*E-mail: fach@ccpo.odu.edu of the marine mammals and seabirds that inhabit the area (Croxall et al. 1988) and the target of a commercial fishery (Murphy et al. 1997). Early analyses of the length frequency distribution of Antarctic krill populations around South Georgia led to the conclusion that the local population is not self-sustaining (Marr 1962, Mackintosh 1972). The apparent lack of a local population that undergoes reproduction with subsequent 


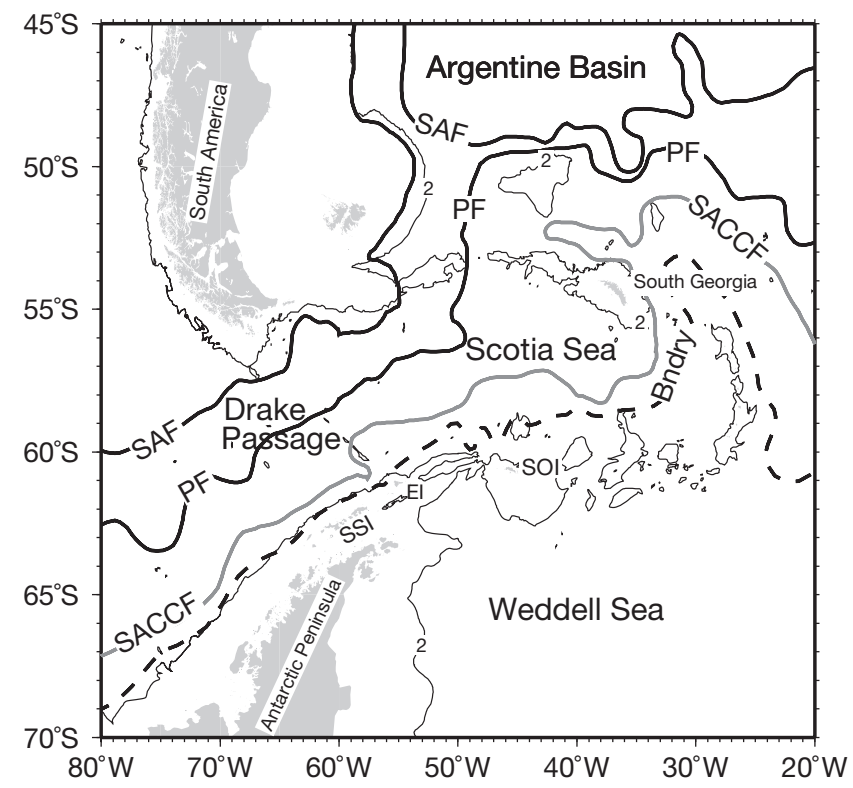

Fig. 1. Base map showing the study region, the locations of the Subantarctic Front (SAF), the Polar Front (PF) the Southern Antarctic Circumpolar Current Front (SACCF), and southern boundary of the Antarctic Circumpolar Current (ACC) (dashed line; Boundry). Front locations determined from historical hydrographic data (Orsi et al. 1995). Thin line represents the $2000 \mathrm{~m}$ isobath. SOI: South Orkney Islands; SSI: South Shetland Islands; EI: Elephant Island

recruitment is surprising considering the large top predator populations that depend on Antarctic krill (Everson 1984). More recent analyses of length frequency distributions suggest that the youngest dominant year class around South Georgia in mid-summer is the 2+ (3 yr old) year class (Murphy et al. 1998, Watkins et al. 1999). Also, Watkins et al. (1999) showed that krill at the eastern end of South Georgia tend to be smaller or lack larger year classes relative to the krill populations at the western end of the Island.

Because there is a persistent krill population at South Georgia, the inference is that the source of this population is elsewhere. The nearest dependable supply of krill (Siegel 1992) is from populations along the western Antarctic Peninsula. Transport of krill from this region to South Georgia is accomplished by the largescale ocean currents (Priddle et al. 1988, Witek et al. 1988). Another potential krill source region is the Weddell Sea (Marr 1962). Atkinson et al. (2001) provide a review of the South Georgia ecosystem and possible krill source populations for this region.

There are few direct observations of krill transport from another region to South Georgia. Distributions of Antarctic krill larval stages between the Antarctic Peninsula and South Georgia (Marr 1962) suggest a spatial separation of stages, with older stages being further eastward. Brinton (1985) used length frequency analyses of krill collected from net samples at locations across the Scotia Sea to show that krill size increases towards South Georgia. This has been supported by Siegel (1992), who found evidence that krill are exported from the Antarctic Peninsula region.

More recently, the issue of krill transport to South Georgia from an upstream source has been tested with modeling studies (Hofmann et al. 1998, Murphy et al. 1998). These studies show that the currents associated with the Antarctic Circumpolar Current (ACC) can transport particles from the Antarctic Peninsula to South Georgia in 140 to $160 \mathrm{~d}$. The currents associated with the Southern ACC Front and southern boundary of the ACC, which flow along the outer continental shelf of the west Antarctic Peninsula, appear to be the primary transport pathways (Hofmann et al. 1998).

Krill of all sizes can potentially be transported by ocean currents. However, passive transport of larval and juvenile krill is most likely because older krill are strong swimmers, with swimming speeds up to 8 times their body length per second (Kils 1982). For $40 \mathrm{~mm}$ krill, this swimming speed is similar to the average speed $\left(30 \mathrm{~cm} \mathrm{~s}^{-1}\right)$ of currents at the Southern ACC Front (Orsi et al. 1995). Modeling studies (Hofmann et al. 1998, Hofmann \& Lascara 2000) suggest that krill with initial sizes of $2 \mathrm{~mm}$ and $10 \mathrm{~mm}$ can develop to 10-12 mm and 20-30 mm, respectively, in 140 to $160 \mathrm{~d}$.

Most krill spawning in the Antarctic Peninsula region occurs between December and February (Ross \& Quetin 1986). Chlorophyll concentrations in the Scotia Sea are typically low $\left(<0.6 \mathrm{mg} \mathrm{m}^{-3}\right.$, Comiso et al. 1993) and transport during and subsequent to the spawning season will place larval and juvenile krill in a low food environment during a time when their potential food supply is declining even further. Thus, while transport of krill across the Scotia Sea to South Georgia is feasible, sufficient food supply during transport or delivery of viable krill to South Georgia is not guaranteed. However, krill are omnivores and exploitation of food sources other than pelagic phytoplankton, such as zooplankton, is possible (Kawaguchi 1986, Daly 1990, Nordhausen et al. 1992), as is feeding on sea ice algae (Marschall 1988, Daly \& Macaulay 1991), which has been observed for larval and juvenile krill. Also, the temperature gradient that krill experience while moving across the Scotia Sea may affect metabolic processes and thus growth (Quetin et al. 1994).

The objective of this paper is to evaluate the food that is required to sustain larval and juvenile Antarctic krill during transport from the Antarctic Peninsula across the Scotia Sea to South Georgia and to suggest potential sources of this food. This is done using a physiologically based model for the growth and development of Antarctic krill (Hofmann \& Lascara 2000) to 
assess the contribution of pelagic phytoplankton, sea ice algae and other potential food sources (e.g. heterotrophic food) to larval growth and development during transport. The role of mesoscale eddies, with associated enhanced levels of chlorophyll, is examined, as is the influence of temperature on the survival of krill during transport. The results of these modeling studies are then used to make inferences about possible source populations for krill and the transport of these to South Georgia.

The model and data sets used in this study are described in the following section, 'Materials and methods'. Simulations of krill growth that are obtained using a range of potential food sources are given in the 'Results'. The 'Discussion' then provides an assessment of the effects of food resources, temperature, and environmental variability on krill transport across the Scotia Sea. The implications of these for krill transport patterns are also considered.

\section{MATERIALS AND METHODS}

Krill growth model. Simulations of Antarctic krill growth and development are obtained using the model described in Hofmann \& Lascara (2000). This size-structured, physiologically based model gives the time-dependent $(t)$ change in the number of krill individuals $(N)$ in a given size class, $j$, as:

$$
\frac{\mathrm{d} N_{j}}{\mathrm{~d} t}=-\alpha_{j} N_{j}-\beta_{j} N_{j}+\alpha_{j-1} N_{j-1}+\beta_{j+1} N_{j+1}
$$

where each size class is defined by a length and associated carbon weight, as determined by the relationships in Table 1 . The rate of transfer between size classes is given by the coefficients $\alpha$ and $\beta$, which are determined by changes in net production based on carbon weight as described below.

Net production of any given size class, $\mathrm{NP}_{j}$, is assumed to be the difference between assimilated ingestion $\left(\mathrm{AI}_{j}\right)$ and respiration $\left(R_{j}\right)$ :

$$
\mathrm{NP}_{j}=\mathrm{AI}_{j}-R_{j}
$$

When $\mathrm{NP}_{j}>0$, the gain in krill biomass (growth) affects a transfer to the next larger size class $\left(\alpha_{j}>0\right.$ and $\left.\beta_{j}=0\right)$.
For $\mathrm{NP}_{j}<0$, the loss in krill biomass (shrinkage) is represented by the transfer of individuals to the next smaller size class $\left(\alpha_{j}=0\right.$ and $\left.\beta_{j}>0\right)$. These transfers are affected by using conversions between length and biomass given in Table 1.

Assimilated ingestion $\left(\mathrm{AI}_{j}\right)$ for each size class is determined from the product of assimilation efficiency $(\gamma)$, krill filtration rate $\left(F_{j}\right)$, and ambient food concentration $(\operatorname{food}(t))$ as:

$$
\mathrm{AI}_{j}=\gamma F_{j} \operatorname{food}(t)
$$

where the assimilation efficiency is set to $80 \%$ for all size classes.

Filtration rate is given by relationships for compression filtration that represent grazing on pelagic phytoplankton concentrations and grazing on sea ice algae (Table 2). Ambient food is input by time series specified externally and is composed of different types and concentrations of food as described below. 
Respiration rate for each size class $\left(R_{j}\right)$ is composed of a standard metabolic rate $\left(R_{j}^{\mathrm{s}}\right)$ which increases due to active feeding $\left(R_{j}^{\mathrm{f}}\right)$ and decreases due to reduced activity levels $\left(R_{j}^{\mathrm{a}}\right)$ in the winter as:

$$
R_{j}=R_{j}^{\mathrm{s}}\left(1+R_{j}^{\mathrm{f}}+R_{j}^{\mathrm{a}}\right)
$$

The relationships used for $R_{j}^{\mathrm{s}}$ are given in Table 2 . Those used to describe the effects of active feeding and activity levels are based on field and experimental studies and are described in Hofmann \& Lascara (2000).

The model given by Eq. (1) was configured with 232 size classes representing krill from $2 \mathrm{~mm}$ (Calyptopis I, first feeding stage) to $60 \mathrm{~mm}$ (maximum adult size), with a resolution of $0.25 \mathrm{~mm}$. The size class model was solved numerically using a 3rd order Adams-Bashforth method (Canuto et al. 1988) with a time step of $0.1 \mathrm{~d}$, which ensured that krill biomass and number of individuals were conserved over the duration of the simulation.

The simulated krill growth rate is limited to $0.25 \mathrm{~mm}$ per time step to ensure that krill do not grow more than 1 size class per day. This maximum rate is in excess of observed summer krill growth rates, which range between 0.105 and $0.179 \mathrm{~mm} \mathrm{~d}^{-1}$ (Rosenberg et al. 1986), as well as overall krill growth rates (Siegel \& Kalinowski 1994) and maximum summer growth rates (Ross et al. 2000). However, it is less than the krill growth rate of $0.33 \mathrm{~mm} \mathrm{~d}^{-1}$ estimated by Clarke \& Morris (1983).

Krill shrink when they do not encounter enough food to meet their metabolic needs and they are starving (Ikeda \& Dixon 1982, Nicol et al. 1992). Ikeda \& Dixon (1982) show that the decrease in body wet weight of krill starved over $211 \mathrm{~d}$ ranged from 32.1 to $52.2 \%$ with a mean decrease of $45 \%$. Thus, for the krill growth model, a loss of krill body wet weight of $45 \%$ is assumed to be equivalent to the death of the animal and the simulations are ended at this point. Larval krill of the Calyptopis I stage have less tolerance to starvation (Ikeda 1984a,b). Therefore, Calyptopis I krill are assumed to die after $6 \mathrm{~d}$ without feeding. Additional mortality due to predation is not included in the krill growth model because the model is designed to represent individual animals.

Particle displacement. The Lagrangian model results presented in Hofmann et al. (1998) show that particles entrained in the current associated with the Southern ACC Front along the western Antarctic Peninsula continental shelf coalesce to a narrow region as they move across the Scotia Sea. For this study, 4 of these particle trajectories, which represent a range of initial positions, were extracted from the many calculated with the Lagrangian model (Fig. 2). The trajectories provide particle locations across the Scotia Sea, which are then

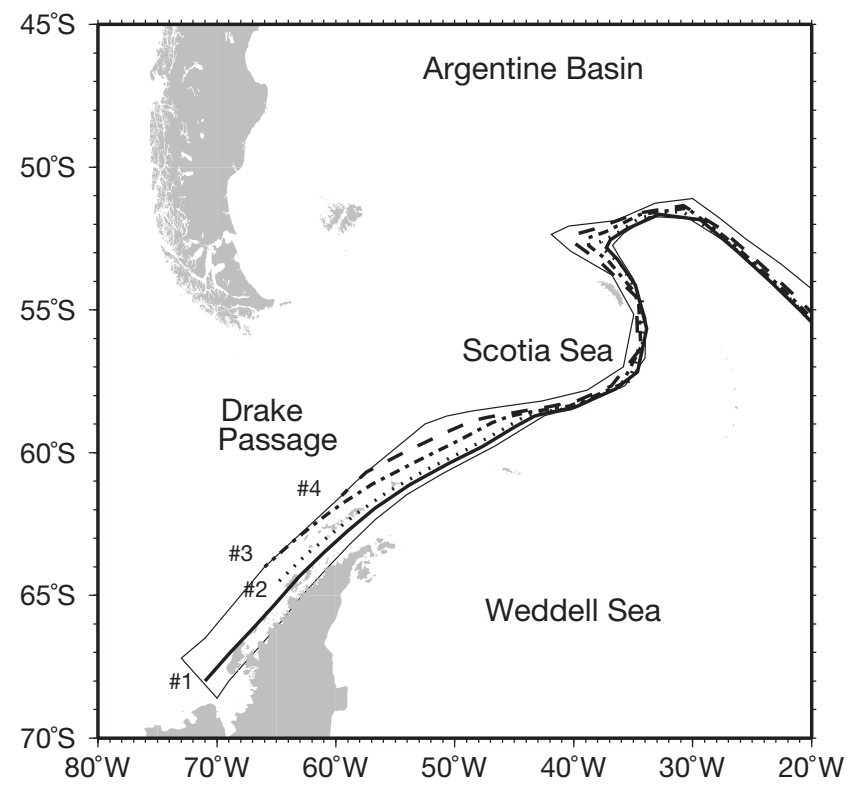

Fig. 2. Particle trajectories obtained from a Lagrangian model that used a circulation field which included the surface Ekman and large-scale climatological flows (Hofmann et al. 1998). Four of the simulated particle trajectories, which represent a range of initial positions, are shown. Thin solid lines encompass the region through which the simulated particles moved

matched with other data sets described in the next section to obtain a time series of available food along a specific transport pathway. To look at the effect of different times of particle release, the trajectories were assumed to apply in January and February. The time required for the 4 surface drifters chosen for this study to move from release sites along the Antarctic Peninsula to South Georgia is 190, 160, 180 and $130 \mathrm{~d}$ for Drifter 1, 2, 3 and 4, respectively. These values bracket the average transport time of 140 to $160 \mathrm{~d}$ calculated for all the surface drifter trajectories (Hofmann et al. 1998).

Food availability. Phytoplankton: Time series of food concentration are needed as input to the krill growth model. Ship-based observations sufficient to construct pelagic phytoplankton distributions across the Scotia Sea do not exist. Therefore, phytoplankton concentrations along the particle trajectories were extracted from monthly chlorophyll distributions that were constructed from 8 yr composites (1978 to 1986) of Coastal Zone Color Scanner (CZCS) observations from the Scotia Sea (Feldman et al. 1989), which are the only large-scale views of chlorophyll concentration for this region. Ocean color measurements from the Sea-viewing Wide Field-of-view Sensor (SeaWiFS) are not yet adequate for describing the chlorophyll distribution of this region because the extensive cloud cover, 
long periods of darkness and seasonal sea ice cover result in considerable gaps in the spatial and temporal coverage. This will become less of an issue as the SeaWiFS time series in this region becomes longer and data can be combined to fill in areas where cloud and sea ice cover is frequent.

The CZCS composites for January and February (Fig. 3A,B) show regions of high chlorophyll concentration $\left(10 \mathrm{mg} \mathrm{m}^{-3}\right)$ along the coast of South America, at isolated locations across the Scotia Sea and along the west Antarctic Peninsula. Chlorophyll concentrations for January are generally higher than those in February, with more regions of high concentration along the west Antarctic Peninsula in the pathways of the drifters. The chlorophyll concentration time series input to the krill growth model were extracted from consecutive monthly CZCS composites, not just from the January and February images shown in Fig. 3. The minimum concentration for CZCS-derived chlorophyll is $0.039 \mathrm{mg} \mathrm{m}^{-3}$, which is the threshold concentration for the sensor. This value is used in low chlorophyll periods such as that between Days 140 and 181 (Fig. 3C), and provides a low-level background chlorophyll value.

The CZCS sensor underestimates chlorophyll concentrations below $1.0 \mathrm{mg} \mathrm{m}^{-3}$ and tends to overestimate concentrations above this value when the global processing algorithm is used (Balch et al. 1992). Also, most of the chlorophyll signal detected by the satellite is from the upper 20 to $25 \%$ of the euphotic zone (Gordon \& McCluney 1975), which is defined as the $1 \%$ light level. Thus, chlorophyll deeper than this could not be detected by the CZCS. However, the mean summer pigment (chlorophyll $a$ and phaeopigment) concentration computed with the Southern Ocean algorithm, which was used to construct the chlorophyll
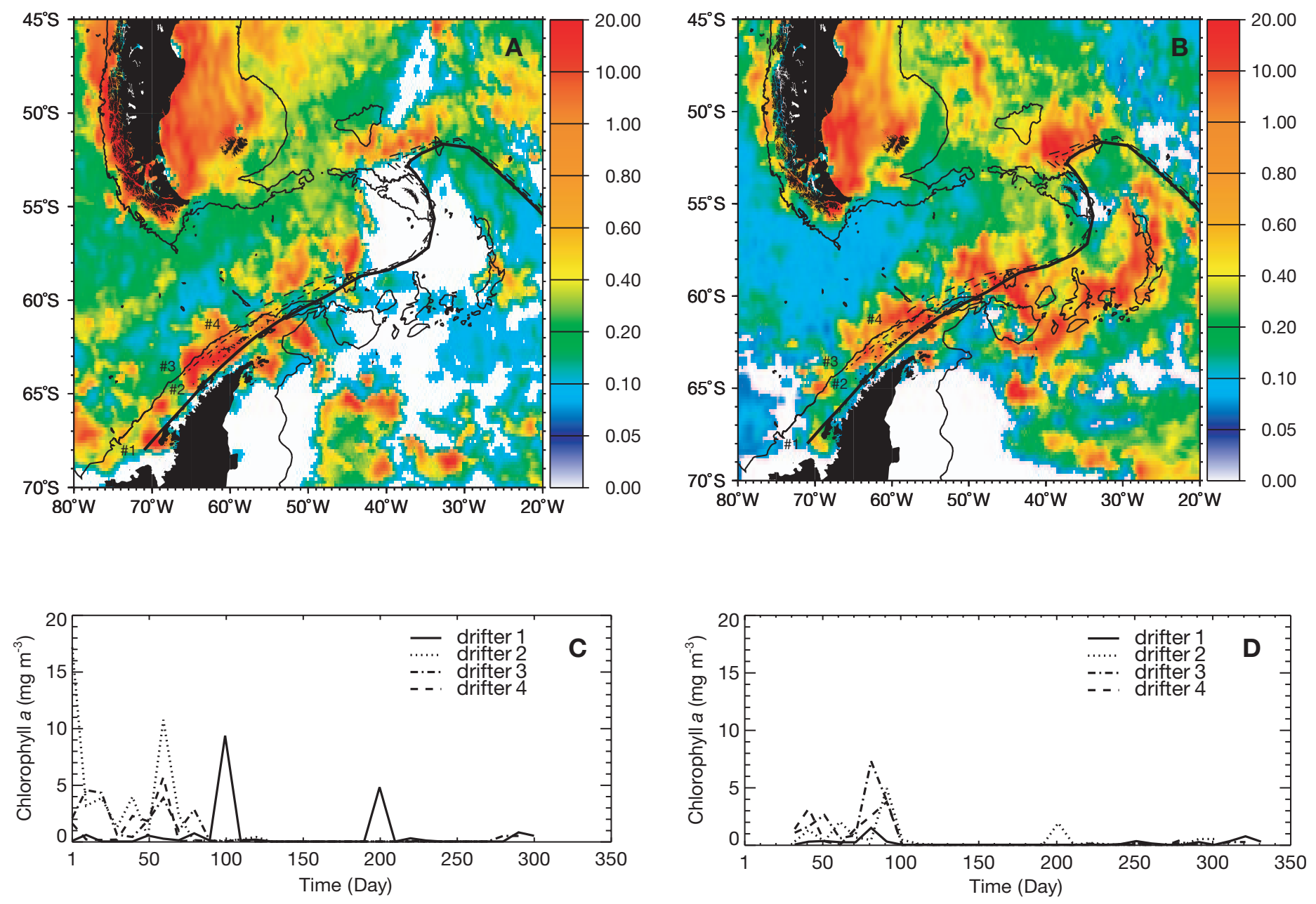

Fig. 3. CZCS-derived 8 yr (1978 to 1986) composite of pigment concentration ( $\mathrm{mg} \mathrm{m}^{-3}$ ) for the months: (A) January, and (B) February. Time series of pigment concentration $\left(\mathrm{mg} \mathrm{m}^{-3}\right)$ along the particle trajectories extracted from the CZCS images starting in (C) January (Day 1) and (D) February (Day 32) 
distributions used in this study, is within $5 \%$ of in situ data (Sullivan et al. 1993).

The chlorophyll concentrations that are encountered along the 4 trajectories by a particle released near the west Antarctic Peninsula on the first day of January (Day 1), which assumes a December krill spawning, are between 3 and $5 \mathrm{mg}$ chl a m${ }^{-3}$, with occasional higher values (Fig. 3C). The chlorophyll time series for particles released the first day of February (Day 32) along the same trajectory (Fig. 3D), which assumes a January spawning, show persistent but lower chlorophyll concentrations until about early April (Day 92), after which values decrease. The extracted chlorophyll time series illustrate the large mesoscale variability in food supply that is encountered along trajectories which are not largely separated in space (Fig. 2). Also, considerable temporal variability occurs in chlorophyll depending on the time a particle leaves the west Antarctic Peninsula.

The contribution of transient features to the overall food supply is not included in the chlorophyll time series derived from the CZCS observations because of the $8 \mathrm{yr}$ average that was used to obtain the monthly composites. Thus, the CZCS-derived chlorophyll concentrations are best regarded as a background food supply, as they provide only a static picture. The Scotia Sea region, however, is known to have considerable mesoscale variability in physical and biological distributions (Murphy et al. 1998). This mesoscale variability was introduced in the food time series constructed from the CZCS composites by superimposing, in an ad hoc manner, occasional high chlorophyll events. These events are intended to represent chlorophyll concentrations associated with mesoscale eddies that move across the Scotia Sea. The frequency and duration of the imposed events is based on the occurrence of mesoscale eddies observed in World Ocean Circulation Experiment (WOCE) surface drifter trajectories (Fig. 4A), which suggest that, on average, 4 to 5 eddies, with a drifter entrainment time of 14 to $17 \mathrm{~d}$, can be present in the Scotia Sea. Based on these characteristics, a time series with elevated chlorophyll a concentrations and different duration times was created (Fig. 4B). The concentration of chlorophyll in the eddies is scaled to the average chlorophyll concentration seen in the CZCS images from the Scotia Sea (see Fig. 3).

Sea ice algae: Sea ice algae provides an additional food source for krill (Marschall 1988, Daly \& Macaulay 1991). Therefore, sea ice concentrations along the 4 particle trajectories were extracted from Special Sensor Microwave Radiometer (SSMR) measurements during a low-ice year, 1985 (Fig. 5), and Special Sensor Microwave/Imager (SSM/I) measurements during a high-ice year, 1988 (Fig. 6) for start times of 1 Janu-
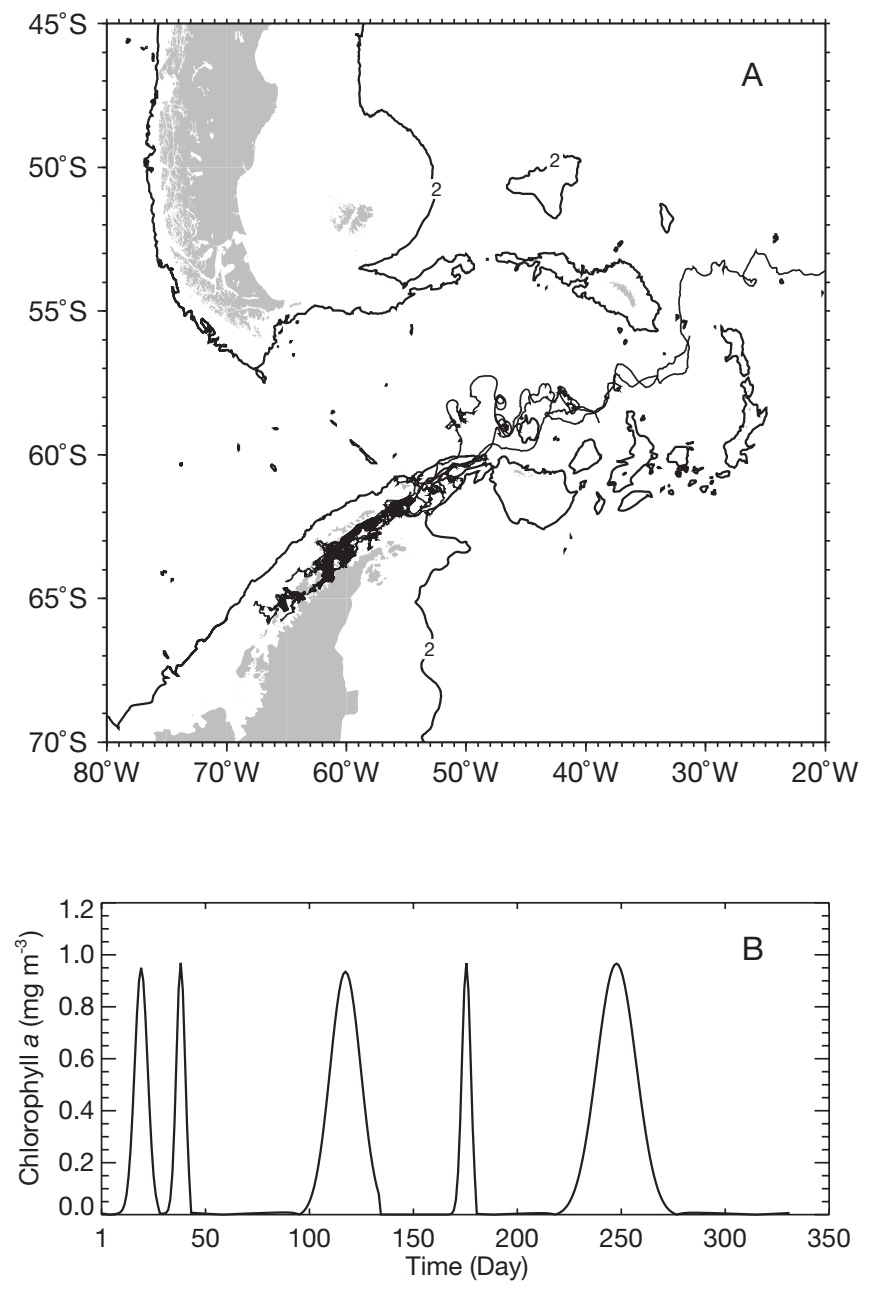

Fig. 4. (A) Trajectories of selected WOCE/TOGA surface drifters released in the Scotia Sea region 1989/90 and 1991/92. (B) Time series of chlorophyll concentrations constructed based on characteristics of the mesoscale features seen in the drifter trajectories

ary and 1 February. For both years the June (Figs. 5A \& 6A) and July (Figs. 5B \& 6B) images are shown, since this is the time when sea ice coverage is potentially important in krill development (Siegel \& Loeb 1995). The percentage of sea ice coverage was then used as a proxy for sea ice biota concentrations and was scaled to a sea ice algae concentration using the sea ice algae time series given in Hofmann \& Lascara (2000).

Sea ice concentrations are generated using brightness temperatures derived from passive microwave data. Comparisons of sea ice concentrations and sea ice edges, obtained from the satellite sensors, with in situ and other satellite data show good agreement (Comiso \& Sullivan 1986). In areas of polynya and lead formation and at the sea ice edge, large errors can 

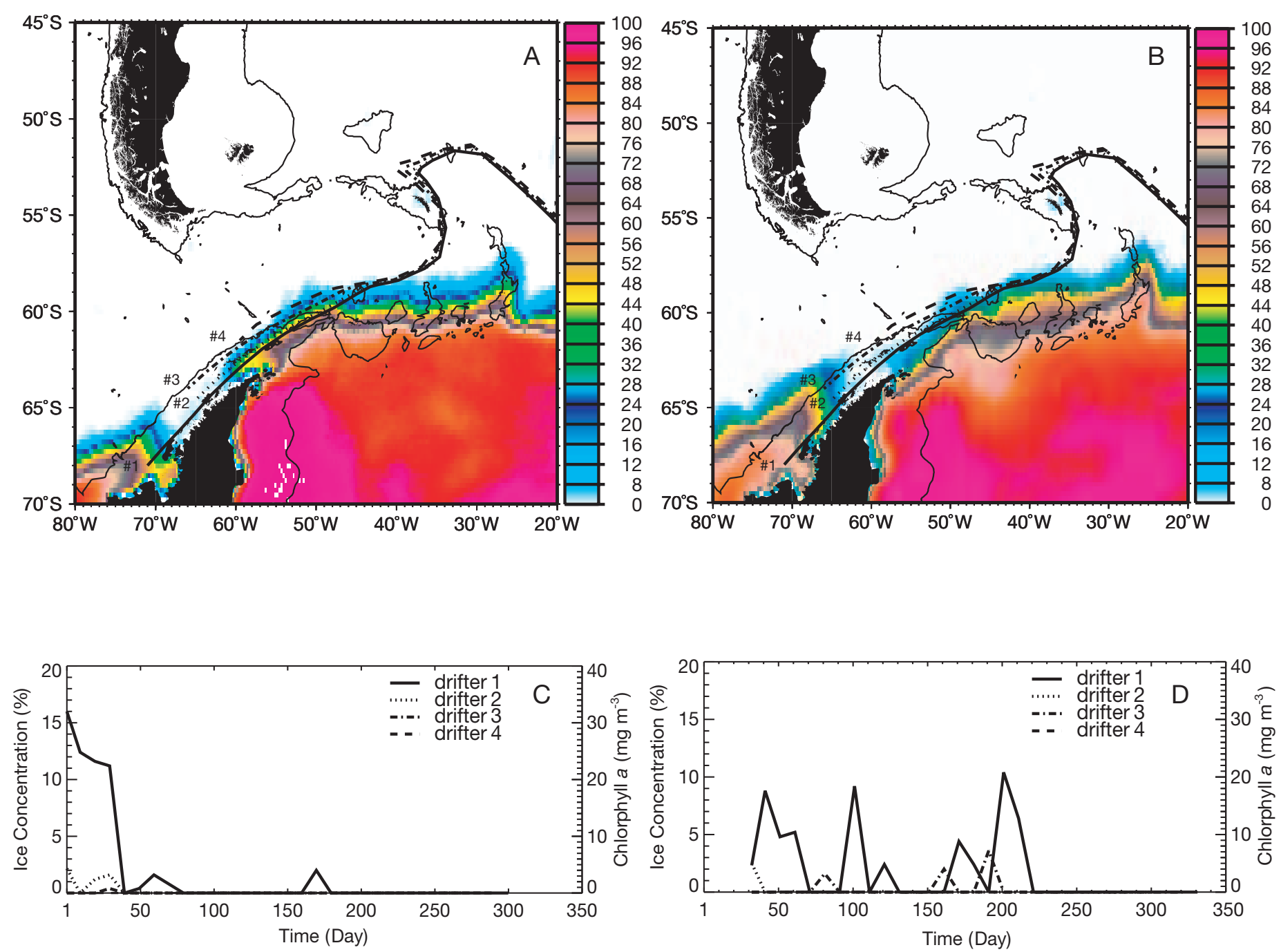

Fig. 5. SSMR-derived sea ice concentration (\% coverage) for (A) June 1985 and (B) July 1985. Time series of sea ice concentration (\% coverage) and pigment concentration $\left(\mathrm{mg} \mathrm{m}^{-3}\right)$ along the particle trajectories extracted from the SSMR images starting in (C) January (Day 1) and (D) February (Day 32)

occur because the emissivity of new sea ice varies continuously with thickness up to several centimeters (Comiso et al. 1989). However, these errors do not affect this analysis because the satellite-derived sea ice distributions are used to obtain general patterns and trends.

The trajectory of Drifter 1 encounters the most sea ice, and hence sea ice algae food, during transit to South Georgia. Thus, the food concentrations encountered along this trajectory were used as the basic phytoplankton and sea ice algae time series input to the model, although Drifter 1 does not necessarily encounter the highest phytoplankton concentrations along its trajectory. The sea ice-derived food time series available to krill along the Drifter 1 trajectory differs between the years 1985 and 1988 (Fig. 7 A,B).
The combined CZCS-derived phytoplankton and the eddy-associated phytoplankton time series for Drifter 1 released in January (Fig. 7A, solid line) and in February (Fig. 7B, solid line) are shown for comparison.

Sea ice-derived food is assumed to be an alternative food source that krill can exploit if they encounter sea ice during transport. This is implemented in the model by allowing krill to feed only on sea ice-derived food when sea ice is encountered along a trajectory.

Heterotrophic food: Studies (e.g. Hopkins et al. 1993, Pakhomov et al. 1997) show that Antarctic krill can feed on zooplankton outside of phytoplankton bloom periods. Thus, a final modification to the food time series consisted of adding a heterotrophic food 

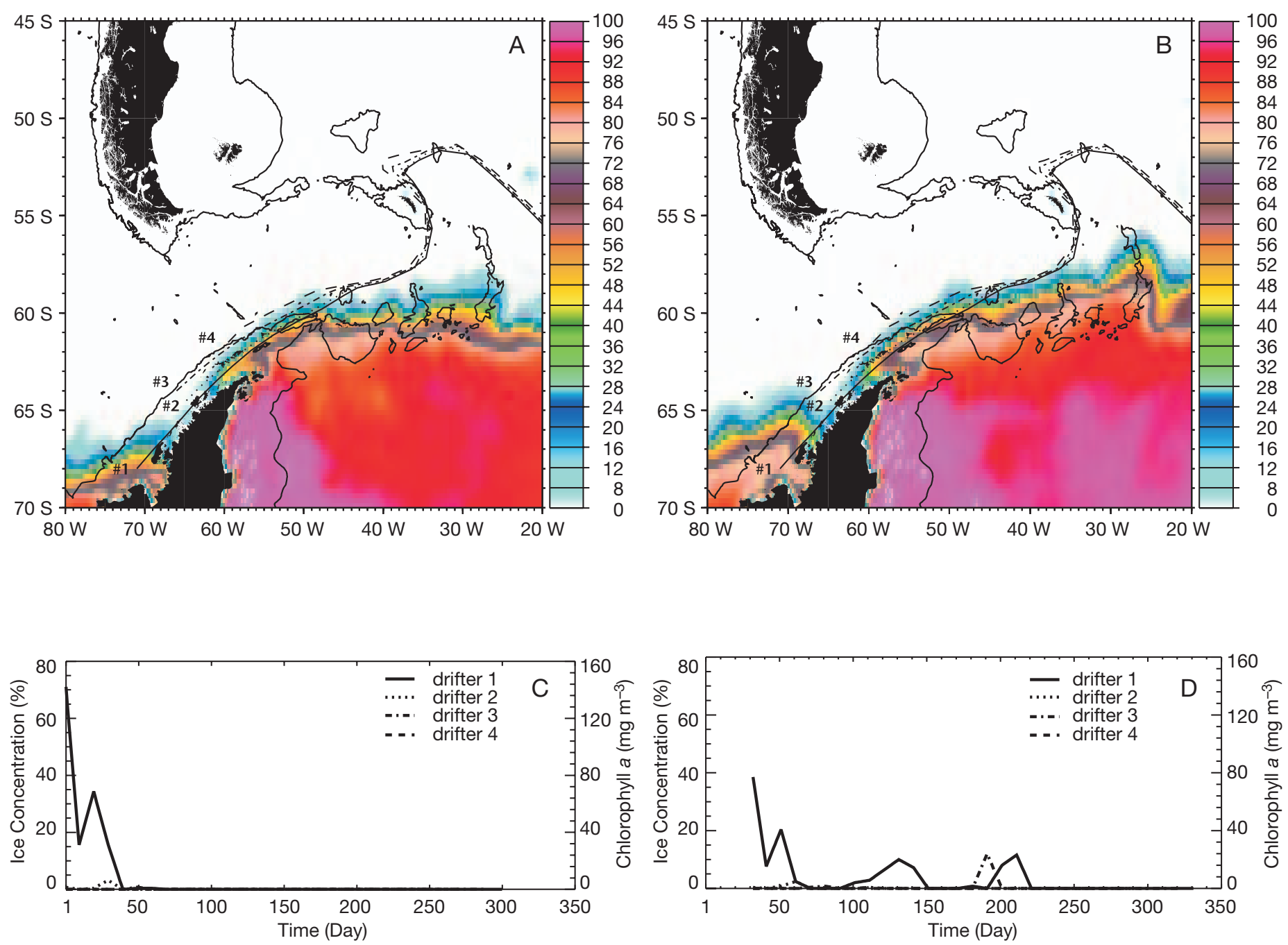

Fig. 6. SSM/I-derived sea ice concentration (\% coverage) for (A) June 1988 and (B) July 1988. Time series of sea ice concentration (\% coverage) and pigment concentration $\left(\mathrm{mg} \mathrm{m}^{-3}\right)$ along the particle trajectories extracted from the SSM/I images starting in (C) January (Day 1) and (D) February (Day 32)

source. Again there are no continuous measurements of copepod concentrations across the Scotia Sea. Therefore, this time series (Fig. 7C,D) was constructed using estimates of mean mesozooplankton biomass in the greater South Georgia region (Atkinson \& Snÿder 1997). Adding this food source to the combined background and eddy-associated food time series gives a total available food time series for January and February release times (Figs. 7E,F). Larval krill are probably not capable of feeding on the large copepods on which the heterotrophic food source is based, due to their small body size. Thus, feeding on the heterotrophic food source is done only by krill greater than $18 \mathrm{~mm}$ in size. Juvenile krill of this size have been observed feeding on copepods (Granéli et al. 1993, Huntley et al. 1994).
Temperature influence. The range in temperature $\left(-1.8\right.$ to $\left.4^{\circ} \mathrm{C}\right)$ that Antarctic krill encounter across the Scotia Sea is large enough to potentially affect metabolic processes associated with growth (Clarke \& Morris 1983, Quetin et al. 1994). Therefore, the influence of temperature on krill growth rate was included through a $Q_{10}$ relationship. Laboratory measurements of temperature effects on the metabolic processes of euphausiids provide $Q_{10}$ values of 2 (Torres \& Childress 1983) and values calculated for Antarctic krill are as high as 3.5 (Quetin et al. 1994). There are few experimental observations from which a temperature dependent growth rate for Antarctic krill can be derived (e.g. Poleck \& Denys 1982, Morris \& Keck 1984, Buchholz 1985, Ikeda et al. 1985) and the limited data represent different experimental designs, differ- 

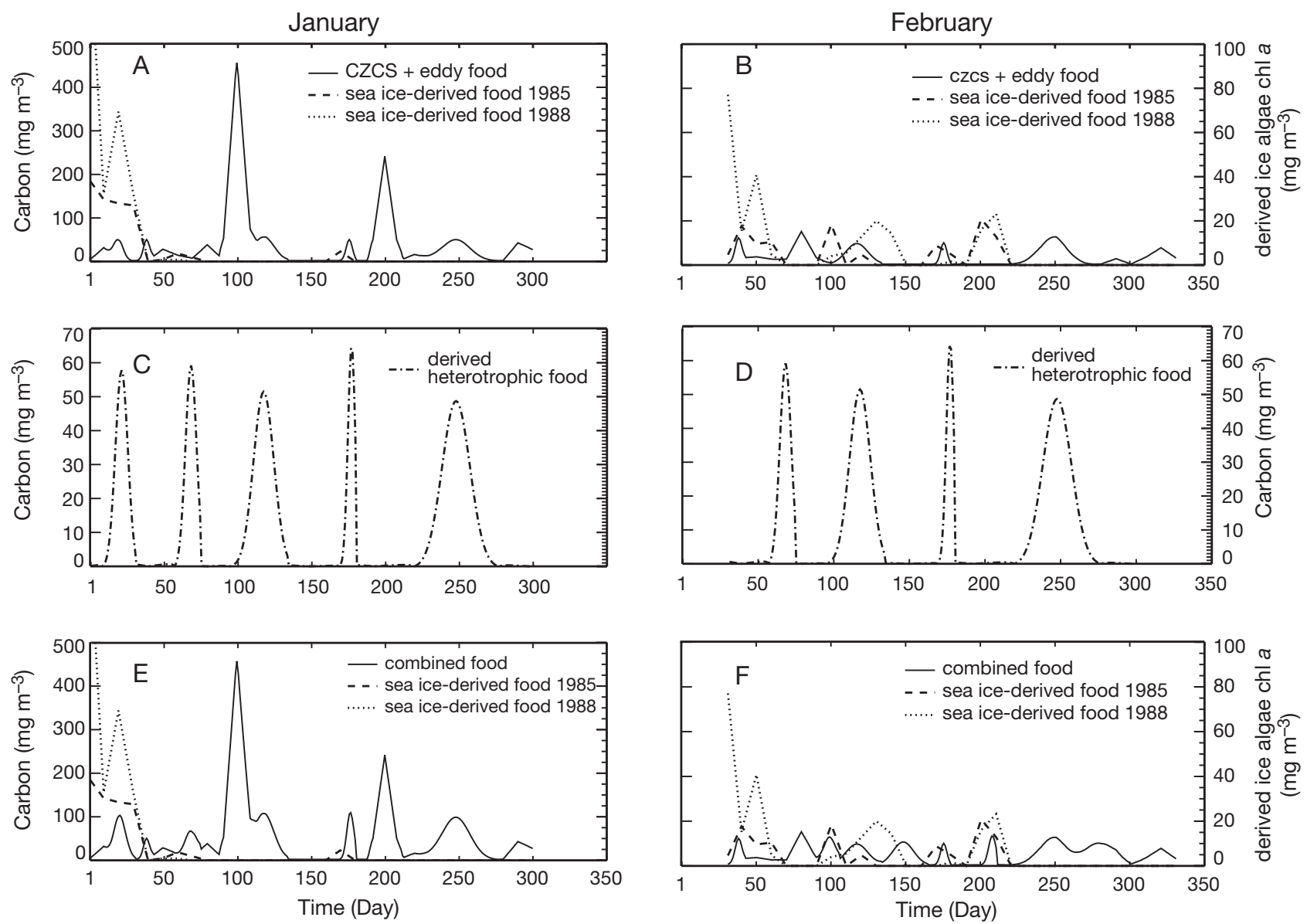

Fig. 7. Time series of food input to the krill growth model for Drifter 1 released along the west Antarctic Peninsula in January $(\mathrm{A}, \mathrm{C}, \mathrm{E})$ and February $(\mathrm{B}, \mathrm{D}, \mathrm{F})$. Individual food time series are defined in each panel

ent-sized krill, and different feeding frequencies, which are not compatible. Therefore, the maximum value reported, a $Q_{10}$ of 3.5 , was used with this model since this represents the maximum effect that can be expected from temperature.

Temperature values along the drifter trajectories, which represent the upper $20 \mathrm{~m}$, were obtained from the National Oceanographic Data Center (NODC) climatology (Boyer \& Levitus 1994). These values and the $Q_{10}$ of 3.5 were used to scale the Antarctic krill growth rates obtained from the model.

\section{RESULTS}

Simulations were done with the krill model to test the effect of the different food availability time series on krill growth and development. The simulations are summarized in Table 3 and the results of each are discussed in the following section.

\section{Different food sources}

Krill exposed to the food time series of pelagic phytoplankton extracted along Drifter 1 (Fig. 3C), starting in

Table 3. Summary of the simulation results obtained using different food availability time series for krill released in January and February. Food time series are designated asPP: pelagic phytoplankton; SIF: sea ice-derived food; EF: eddy-associated food; and HF: heterotrophic food

\begin{tabular}{|lccc|}
\hline Food assumption & $\begin{array}{c}\text { Food time } \\
\text { series }\end{array}$ & $\begin{array}{c}\text { January } \\
\text { release } \\
\text { results }\end{array}$ & $\begin{array}{c}\text { February } \\
\text { release } \\
\text { results }\end{array}$ \\
\hline $\mathrm{PP}$ & Fig. 3C,D & Fig. 8A & Fig. 8B \\
$\mathrm{PP}+\mathrm{SIF}$ & Fig. 3C,D, 6C,D & Fig. 8A & Fig. 8B \\
$\mathrm{PP}+\mathrm{EF}$ & Fig. 7A,B & Fig. 9A & Fig. 9B \\
$\mathrm{PP}+\mathrm{EF}+\mathrm{SIF}$ & Fig. 7A,B & Fig. 9A & Fig. 9B \\
$\mathrm{PP}+\mathrm{EF}+\mathrm{HF}$ & Fig. 7E,F & Fig. 10A & Fig. 10B \\
$\mathrm{PP}+\mathrm{EF}+\mathrm{HF}+\mathrm{SIF}$ & Fig. 7E,F & Fig. 10A & Fig. 10B \\
\hline
\end{tabular}



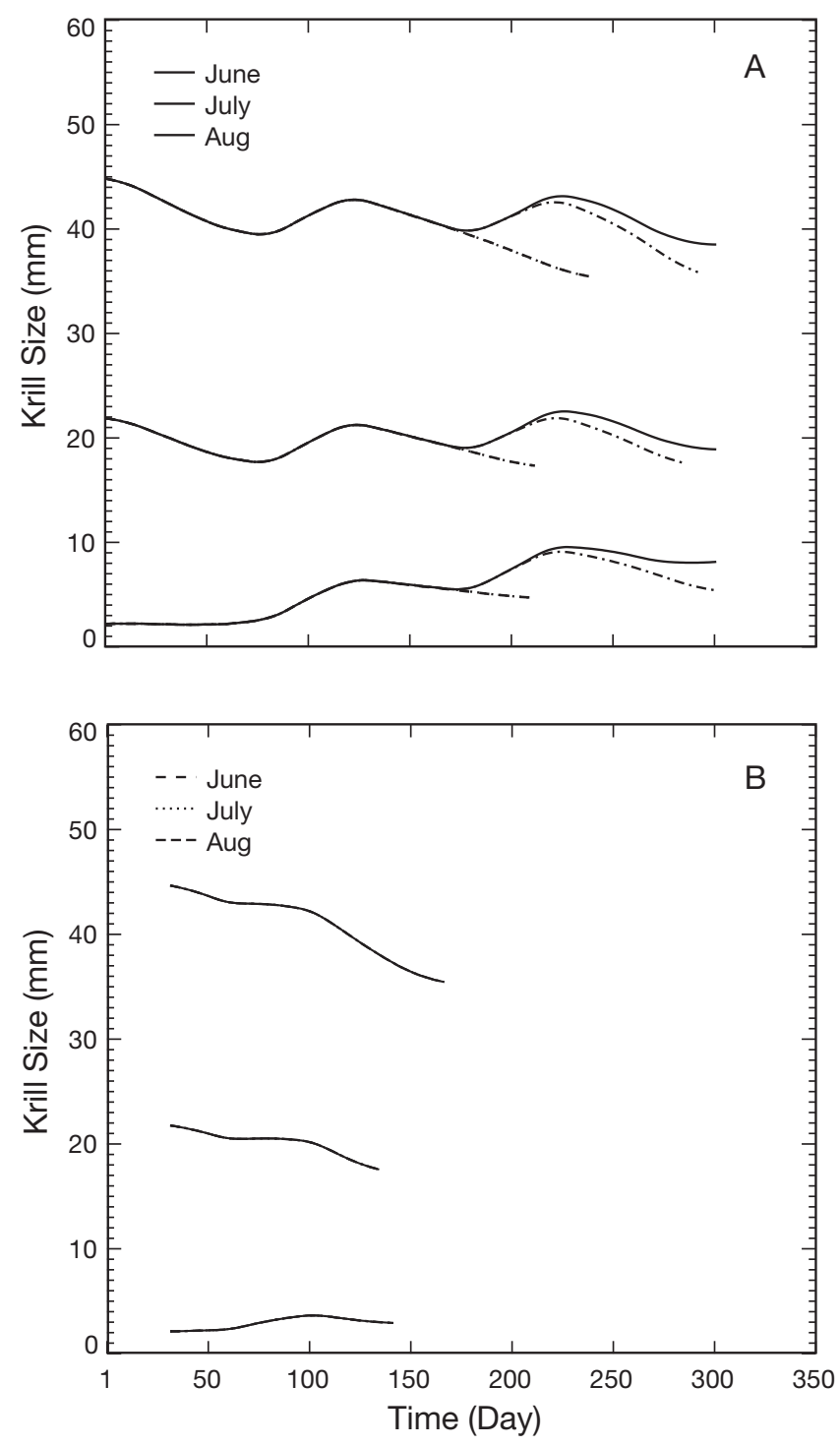

Fig. 8. Simulated growth of $2 \mathrm{~mm}$ krill (lower curves), $22 \mathrm{~mm}$ krill (middle curves), and $45 \mathrm{~mm}$ krill (upper curves) using phytoplankton food only (solid lines). Simulated growth obtained when sea ice food becomes available in June, July and August is also shown (dashed lines). Simulations began (A) January (Day 1) and (B) February (Day 32)

January (Day 1), developed as shown in Fig. 8A (solid lines). Larval krill, with an initial size of $2 \mathrm{~mm}$, represent the result of the current season's spawn, and in this simulation the $2 \mathrm{~mm}$ krill do not grow for the first $90 \mathrm{~d}$. The subsequent presence and absence of food produced periods of decreasing and increasing size. After 140 to $160 \mathrm{~d}$, the transport time from previous modeling studies (Hofmann et al. 1998), the $2 \mathrm{~mm}$ krill grew to 6 to $7 \mathrm{~mm}$.

The simulated growth of $22 \mathrm{~mm}$ krill, which corresponds to the $1+$ age class (subadult), did not increase significantly over the total time of simulation. After 140 to $160 \mathrm{~d}$, the $22 \mathrm{~mm}$ krill shrank to ca. $20 \mathrm{~mm}$. The pattern of growing and shrinking for the adult krill (45 mm) is similar to that for the $22 \mathrm{~mm}$ krill, except that periods of shrinking are more pronounced.

The simulated growth (Fig. 8B, solid lines) of the same 3 krill size classes starting in February (Day 32) shows that all size classes shrank rapidly throughout the simulation due to insufficient food supply (see Fig. 3D) and reached the criteria for dying. The $22 \mathrm{~mm}$ krill died after $142 \mathrm{~d}$ of simulation, the $22 \mathrm{~mm}$ krill after $135 \mathrm{~d}$, and the $45 \mathrm{~mm}$ krill after $167 \mathrm{~d}$.

The effect of sea ice-derived food and the timing of the availability of this food on krill growth was tested by providing the food in June, July, and August. Prior to availability of the sea ice-derived food, krill growth is supported by the background pelagic phytoplankton. For a high ice year (1988), krill exposed to this combined time series have the same growth pattern as obtained by feeding on pelagic phytoplankton only until the sea ice food is available at the beginning of June and July. The available sea ice food is low and is not sufficient to support krill growth; thus, shrinking continues until krill meet the criteria for death (Fig. 8A). Delaying the availability of sea ice-derived food until August results in continued shrinkage of all krill size classes because of insufficient food. For krill released in February, none of the krill live to encounter sea ice (Fig. 8B) and death occurs.

The addition of the mesoscale eddy-associated food results in improved growth of the same 3 krill size classes relative to the previous simulations (Fig. 9A,B). After 140 to $160 \mathrm{~d}$, the larval krill starting in January reached a size of ca. $10 \mathrm{~mm}$, considerably larger than in the simulation that used only pelagic phytoplankton food (Fig. 8A). This size increase in this amount of time is consistent with observations (Siegel \& Kalinowski 1994). Juvenile and adult krill showed similar growth patterns over the simulation, initially decreasing in size and then undergoing periods of growth and shrinkage. At the end of the simulation, the $22 \mathrm{~mm}$ krill had reached $31 \mathrm{~mm}$, and the $45 \mathrm{~mm}$ krill had increased to $49 \mathrm{~mm}$.

Even when starting in February (Day 32), the larval krill slowly increased over time, reaching 6 to $7 \mathrm{~mm}$ after 140 to $160 \mathrm{~d}$ and $9 \mathrm{~mm}$ by the end of the simulation (Fig. 9B). The $22 \mathrm{~mm}$ and $45 \mathrm{~mm}$ krill shrank and showed minimal growth during the simulation. The $22 \mathrm{~mm}$ krill died after $235 \mathrm{~d}$ of simulation.

Including sea ice-derived food had a negative effect on the growth of krill (Fig. 9A,B), no matter when in winter krill switched to feeding on this food source. This is expected because the previous simulations (Fig. 8A) showed that sea ice-derived food by itself is not sufficient to sustain krill. 

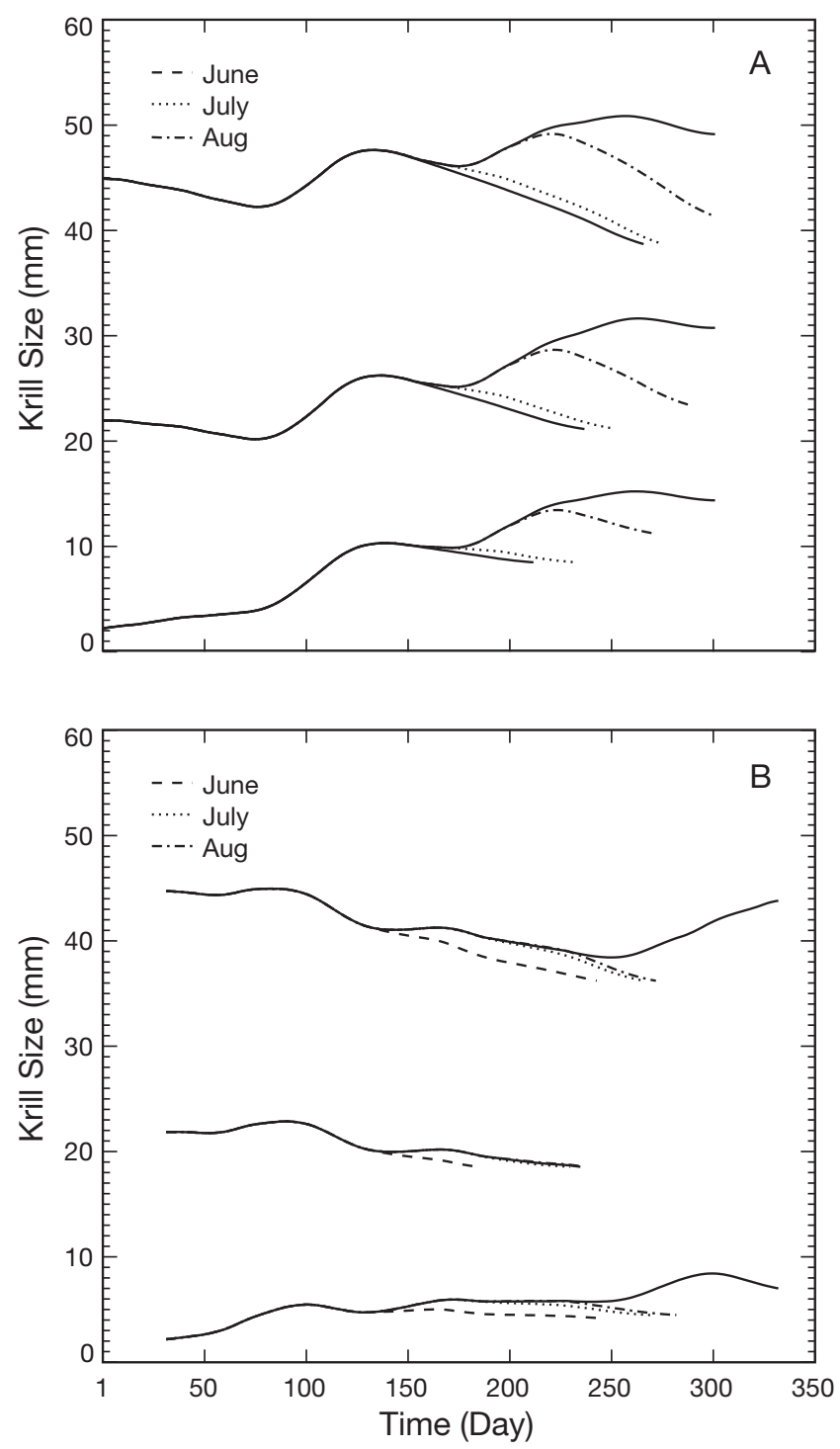

Fig. 9. Simulated growth of $2 \mathrm{~mm}$ krill (lower curves), $22 \mathrm{~mm}$ krill (middle curves), and $45 \mathrm{~mm}$ krill (upper curves) using combined phytoplankton food and eddy-associated food. Simulated growth obtained when sea ice food becomes available in June, July and August is also shown (dashed lines). Simulations began (A) January (Day 1) and (B) February (Day 32)

The final set of simulations consider krill growth that results from the addition of a heterotrophic food source. For a January (Fig. 10A) and a February (Fig. 10B) release, the $22 \mathrm{~mm}$ and $45 \mathrm{~mm}$ krill grow throughout the simulation. The initial growth is slow, with the krill starting in February growing less than those released in January. For a January release, the $22 \mathrm{~mm}$ krill grow to $42 \mathrm{~mm}$ and $45 \mathrm{~mm}$ krill grow to $59 \mathrm{~mm}$ by the end of the simulation, which is consistent with observations (Siegel 1987). The $2 \mathrm{~mm}$ krill feed only on pelagic phytoplankton and as a result do not get larger than $18 \mathrm{~mm}$ over the course of the simulation. Again, encountering sea ice-derived food late in the simulation and exclusive feeding on this food source has a negative effect on the growth of all krill size classes (Fig. 10A,B).

\section{Growth rates}

Daily growth rates associated with $2 \mathrm{~mm}$ krill feeding on combined food (see Fig. 7E,F) for a January (Fig. 11A)
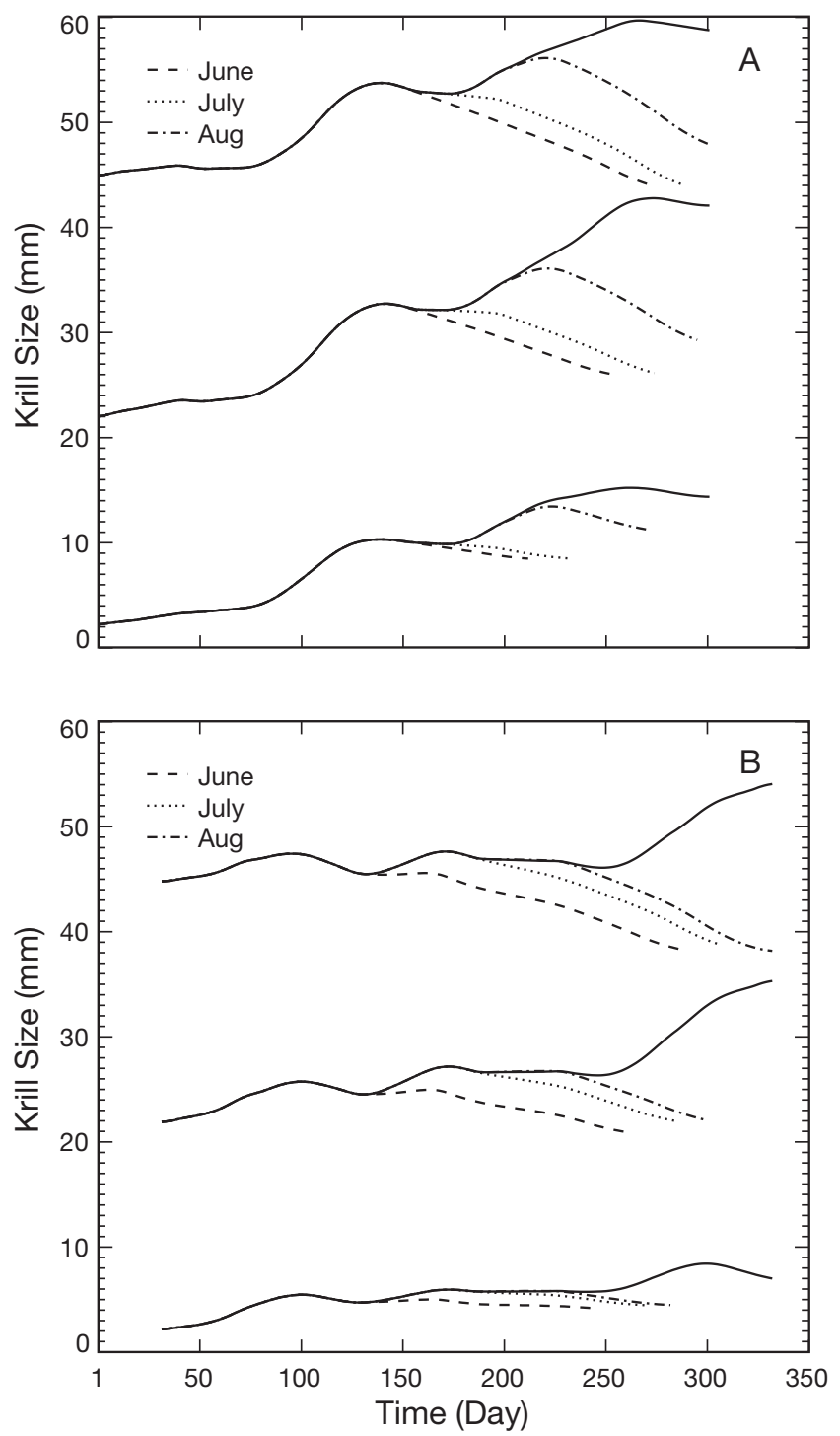

Fig. 10. Simulated growth of $2 \mathrm{~mm}$ krill (lower curves), $22 \mathrm{~mm}$ krill (middle curves), and $45 \mathrm{~mm}$ krill (upper curves) using combined phytoplankton, eddy-associated food, and heterotrophic food (solid lines). Simulated growth obtained when sea ice food becomes available in June, July and August is also shown (dashed lines). Simulations began (A) January (Day 1) and (B) February (Day 32) 

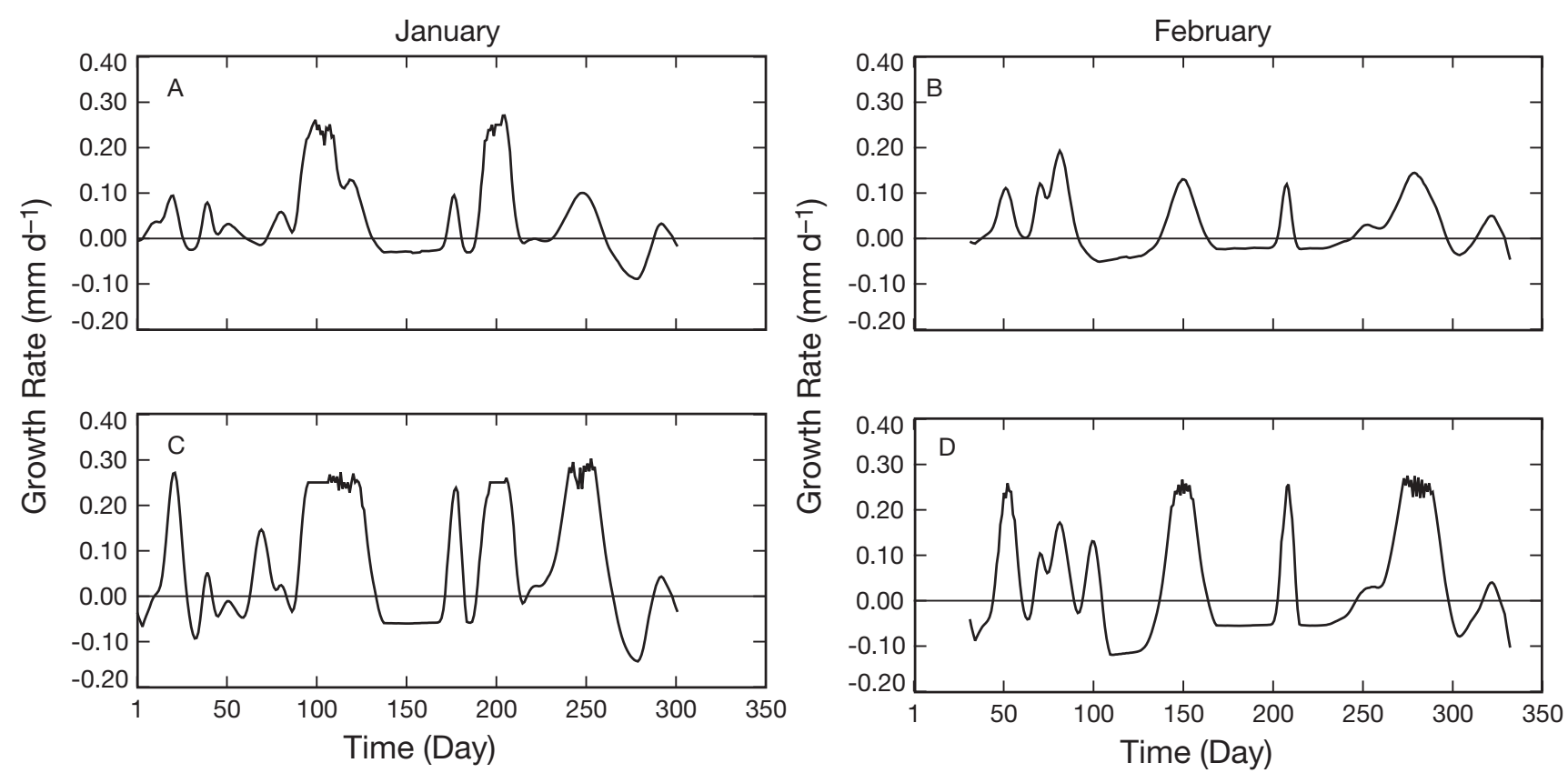

Fig. 11. Simulated daily growth rates of (A) $2 \mathrm{~mm}$ krill feeding on combined food sources beginning in January and (B) February, and for (C) $22 \mathrm{~mm}$ krill feeding on combined food sources beginning in January and (D) February. For food data see Fig. 7D, solid line (January) and Fig. 7E, solid line (February)

and a February (Fig. 11B) release range between -0.09 to $0.271 \mathrm{~mm} \mathrm{~d}^{-1}$ and -0.069 to $0.193 \mathrm{~mm} \mathrm{~d}^{-1}$, respectively. Growth rates in the January simulation are generally higher, due to better food availability. Periods of shrinking occur in both simulations, but more so in February due to less food available.

Growth rates for the $22 \mathrm{~mm}$ krill feeding on the food supply starting in January (Fig. 11C) and February (Fig. 11D) range between -0.14 to $0.303 \mathrm{~mm} \mathrm{~d}^{-1}$ and -0.14 to $0.275 \mathrm{~mm} \mathrm{~d}^{-1}$, respectively. Release in January gives longer periods of high growth rates relative to those for a February release due to greater food availability in January. Growth and shrink rates for the $22 \mathrm{~mm}$ krill are bigger than those for the $2 \mathrm{~mm}$ krill, reflecting the higher metabolic rates of the larger animals. The simulated growth rates are within the range of observed growth rates, which are 0.105 to $0.179 \mathrm{~mm}$ $\mathrm{d}^{-1}$ (Rosenberg et al. 1986) and $0.33 \mathrm{~mm} \mathrm{~d}^{-1}$ (Clarke \& Morris 1983).

\section{Temperature}

The effect of varying temperature on krill growth is estimated by taking the time series of simulated daily growth rates (Fig. 11), which are calculated relative to $0^{\circ} \mathrm{C}$, and rescaling these using the temperature time series extracted along the drifter trajectories from the NODC temperature climatologies and a $Q_{10}$ value of
3.5. The resulting differences between these growth rates and the original growth rates are plotted as percent growth rate change (Figs. 12 \& 13) and indicate the relative effect of temperature and food on krill growth rate.

For the $2 \mathrm{~mm}$ krill starting transport in January and feeding on the combined food time series, the temperature effect is greatest at the maxima and minima of the growth rate time series, which reflect changes in food availability (Fig. 12A). The effect of temperature is most pronounced when high food concentrations coincide with increased temperature, such as the peaks in temperature near Day 100 and Day 200. The coincidence of increased food with elevated temperatures increases the growth rate by a maximum of $3.78 \%$ over the constant temperature simulation. The increased growth rates are of short duration, but are sufficient to have an effect on the final size of the krill. Maintaining the growth rate scaled to a $Q_{10}$ value of 3.5 would result in krill growing an additional $1 \mathrm{~mm}$ over the size reached in the constant temperature simulation.

Larval krill starting transport in February encounter lower temperatures and food during transit (Fig. 12B). As a result, the constant and temperature-dependent growth rates are similar, with the maximum difference between the 2 being only $1.19 \%$, which over the time of the simulation would result in an additional $0.5 \mathrm{~mm}$ in growth. 

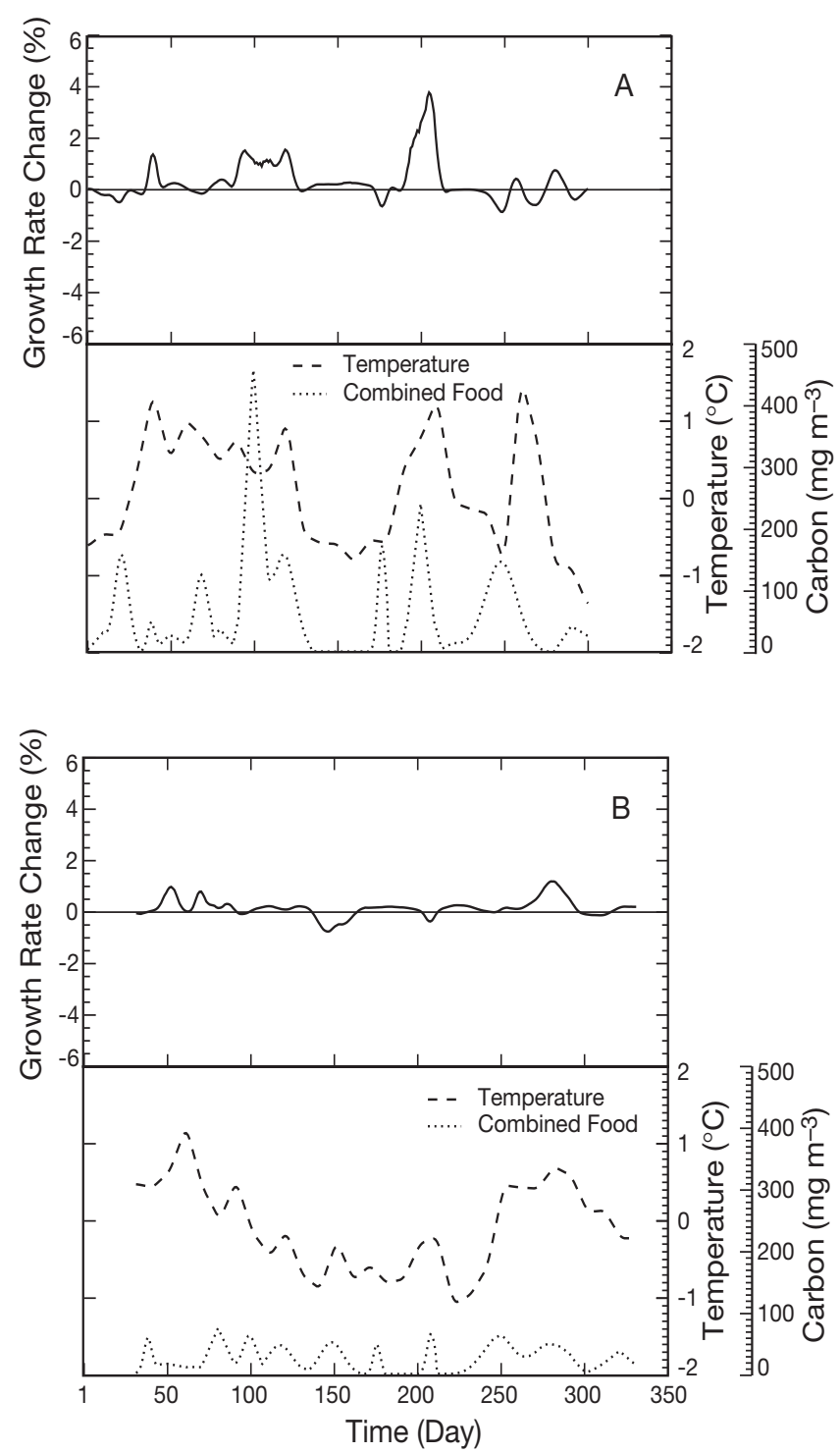

Fig. 12. Time series of the change in growth rate of $2 \mathrm{~mm}$ krill for simulations that begin in (A) January (Day 1) and (B) February (Day 32). Percent change is the difference between the growth rate at a constant temperature of $0^{\circ} \mathrm{C}$ and that obtained with a variable temperature and a $Q_{10}$ of 3.5. The time series of temperature and food availability used in the simulations are shown

The growth rate time series for the $22 \mathrm{~mm} \mathrm{krill}$ is more variable (Fig. 13A,B), and shows more periods of shrinking, relative to that for the $2 \mathrm{~mm}$ krill. The simulation shows that a varying temperature environment has the most influence during times when food is abundant. The maximum effect of temperature for the January simulation occurs near Day 200 when the maximum difference between the constant and temperature-varying growth rates is $3.83 \%$ (Fig. 13A). However, over the entirety of the simulation, tempera-
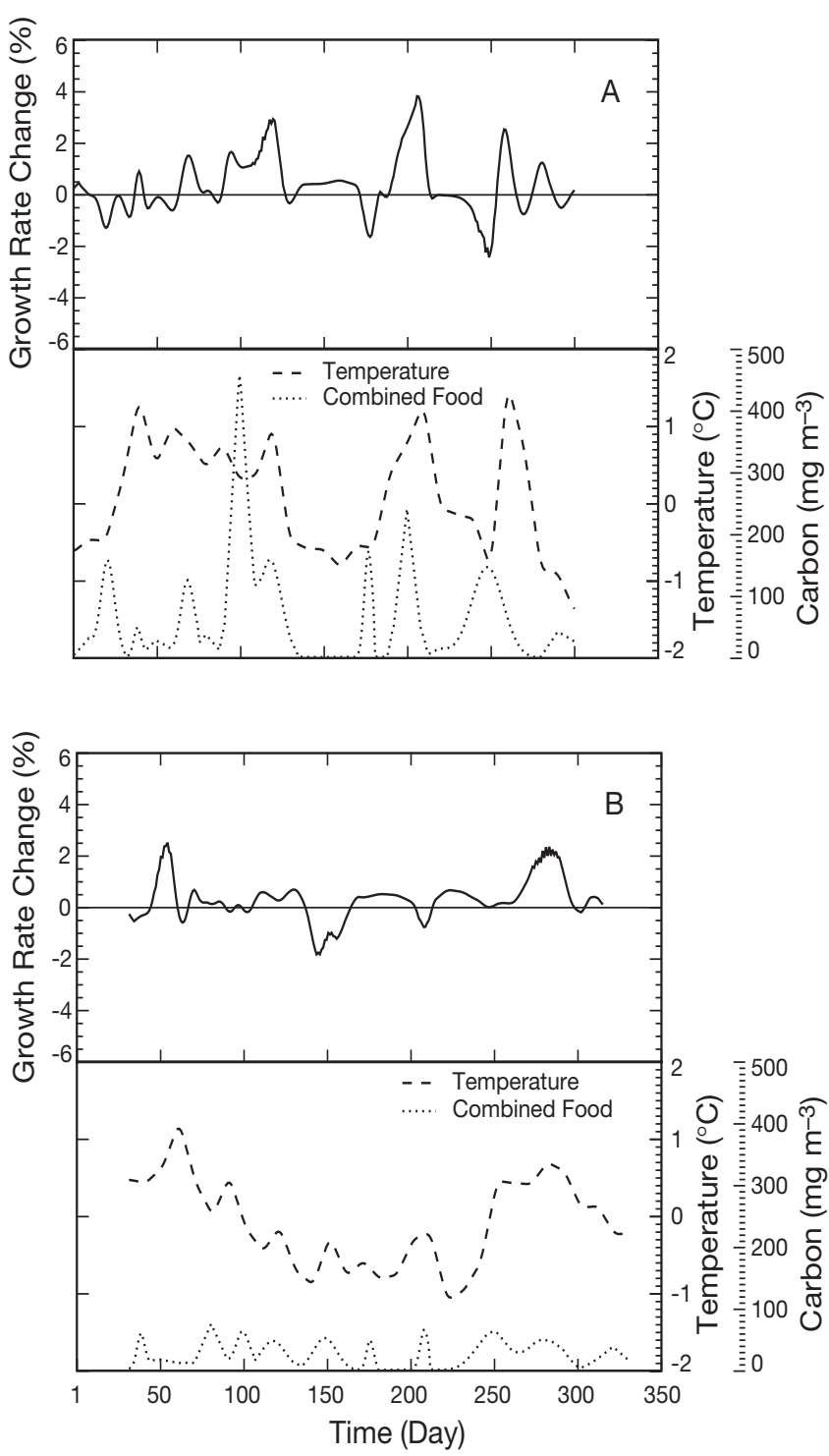

Fig. 13. Time series of the change in growth rate of $22 \mathrm{~mm}$ krill for simulations that begin in (A) January (Day 1) and (B) February (Day 32). Percent change is the difference between the growth rate at a constant temperature of $0^{\circ} \mathrm{C}$ and that obtained with a variable temperature and a $Q_{10}$ of 3.5. The time series of temperature and food availability used in the simulations are shown

ture effects on krill growth are somewhat lessened and the final size of the krill would be $43.37 \mathrm{~mm}$, which is $1 \mathrm{~mm}$ larger than that obtained in the constant temperature simulations.

The growth rates for the simulation beginning in February (Fig. 13B) again show frequent temperature influence when food is abundant at Days 50, 150 and 270 with a maximum difference of $2.52 \%$. These result in an increase in krill size of $1 \mathrm{~mm}$ over the constant temperature simulation. 


\section{DISCUSSION}

\section{Effect of food}

Spawning in either January or February places krill in an environment in the Scotia Sea in which the background chlorophyll concentrations are not always sufficient to support growth during the 140 to $160 \mathrm{~d}$ needed for transport to South Georgia. Larval krill feeding on phytoplankton only reach a size of 6 to $7 \mathrm{~mm}$ or less over that time span. Sea ice concentrations do not provide a good alternative to the pelagic food source since sea ice tends to be low in the Scotia Sea during the austral fall and early austral winter. High concentrations of pelagic phytoplankton entrained in eddies can enhance food concentrations such that larval krill can develop adequately during transport. Larval krill feeding on this enhanced food grow to a size of $10 \mathrm{~mm}$ after 140 to $160 \mathrm{~d}$.

Spawning in January, and therefore an early start to transport, results in more successful krill growth than does spawning later in the season because of higher food availability in the Scotia Sea during the austral summer prior to the rapid decline in phytoplankton concentration during fall. The high simulated growth rates of $0.271 \mathrm{~mm} \mathrm{~d}^{-1}$ obtained for $2 \mathrm{~mm}$ krill (Fig. 12A) exposed to the combined food sources time series are less than the maximum rate of $0.33 \mathrm{~mm} \mathrm{~d}^{-1}$ estimated from repeat sampling of 1 aggregation (Clarke \& Morris 1983). However, this estimate was made for juvenile krill of ca. $30 \mathrm{~mm}$ length and is not likely to be sustained for long periods of time. The high rates for the $2 \mathrm{~mm}$ krill suggest that the parameterization of feeding for these animals may result in an overestimate of ingestion and krill growth. The feeding parameterization for small, $2 \mathrm{~mm}$ size krill is extrapolated from observations for larger krill (Hofmann \& Lascara 2000). Thus, this result points to the need to obtain measurements of metabolic processes for smaller krill.

For larger krill sizes (22 and $45 \mathrm{~mm}$ ), it is apparent that food consisting solely of pelagic phytoplankton is not adequate to support krill maintenance and growth during transport across the Scotia Sea. Krill can barely sustain their initial size when feeding on this as a sole food source. Even the addition of occasional mesoscale patches of high chlorophyll concentration are not completely sufficient to support the growth of these larger animals, which have actually been observed in nature (Siegel 1987). The implication of these simulations is that larger krill need additional food sources during transport across the Scotia Sea. Such a food source can be provided by copepods, dinoflagellates, and ciliates (Atkinson \& Snÿder 1997, Pakhomov et al. 1997), which have been shown to dominate the carbon intake of krill even in phytoplankton carbon dominated water. How- ever, these studies included older krill of the size 25 to $40 \mathrm{~mm}$, or krill as small as $18 \mathrm{~mm}$ (Granéli et al. 1993, Huntley et al. 1994). Alternate food sources for larval krill may be different since feeding on copepods is not an option for these smaller animals. The large-scale distribution of zooplankton and other possible alternate food sources across the Scotia Sea is not known (Smith \& Schnack-Schiel 1990). Atkinson \& Sinclair (2000) and Atkinson et al. (2001) show that total copepod abundance in the Scotia Sea area has a prominent peak in the vicinity of the Polar Front compared to all other regions. The potential importance of this for Antarctic krill survival suggests that measurements of these distributions are needed.

\section{Effect of temperature}

Poleck \& Denys (1982) showed that the growth rate of krill is influenced by temperature in that intermoult periods decreased with increasing temperature, indicating that increased temperature might result in a higher growth rate. Additional experimental work by Ikeda \& Dixon (1982), Morris \& Keck (1984) and Buchholz $(1985,1991)$ support this finding. Thus, temperature effects on krill growth rates potentially influence survival and viability of the krill transported across the Scotia Sea. The upper water column temperature across the Scotia Sea ranges from $-1.8^{\circ} \mathrm{C}$ in winter, up to $4^{\circ} \mathrm{C}$ in summer at the northern limits around South Georgia (Boyer \& Levitus 1994). The proposed transport of krill from the western Antarctic Peninsula across the Scotia Sea to South Georgia will therefore expose krill to this wide range of temperatures.

The simulated larval and juvenile krill growth rates increase in response to increases in temperature, especially when these coincide with increased food supply (Figs. 12 \& 13). However, for the 2 and $22 \mathrm{~mm}$ krill, changes in growth rate due to temperature alone are small relative to those produced by changes in food availability. Therefore, enhancements of growth rate due to increased temperature are not sufficient to compensate for a low food environment. The simulations suggest that the interaction between temperature, food and krill growth are complex. Additional experimental and observational studies are needed in this area, especially for larval and small juvenile krill, in order for it to be understood and explicitly parameterized in growth models.

\section{Role of variability}

The simulation results presented in this study are based on food availability time series derived from 
composite CZCS and sea ice images, which are then combined with idealized representations of food associated with mesoscale eddies and heterotrophic food sources. Thus, the food availability time series represent specific assumptions about how food is distributed across the Scotia Sea. Also once defined, the food availability does not evolve along a given trajectory.

The Scotia Sea is a variable environment. The chlorophyll concentration extracted from the CZCS image for drifter trajectories that are both widely separated in time or space show marked differences (see Fig. 3). Similarly, the sea ice images (Figs. $5 \& 6$ ) and WOCE drifter trajectories (Fig. 4) suggest environmental variability occurring at a large number of scales. Thus, it may be that variability is what makes it possible for krill to survive transport across the Scotia Sea. Investigation of the potential effects of variable food supply on krill growth requires development of lower trophic level models that allow autotrophic and heterotrophic food distributions to evolve in space and time in response to environmental conditions.

The circulation across the Scotia Sea and in the environs around South Georgia is affected by variability in the location of the ACC fronts and is characterized by mesoscale eddies (Brandon et al. 1999). Some evidence suggests that flow may be coherent over the region. Oscillations in krill biomass at Elephant Island (see Fig. 1) have been shown to coincide with oscillations in krill biomass at South Georgia (Brierly et al. 1999). However, the degree of coherence in circulation over this region remains to be determined, as does its effect on krill transit times and pathways.

Connections among Antarctic krill populations in the west Antarctic Peninsula, the Weddell Sea, across the Scotia Sea, and at South Georgia are likely to be complex. Circulation variability may produce multiple transport pathways, which may have different effects on different sized krill. Further evaluation of transport of Antarctic krill across the Scotia Sea needs to be done within the framework of a general ocean circulation model that is coupled with a krill growth model.

\section{Implications for transport to South Georgia}

It is feasible that krill spawned along the western Antarctic Peninsula provide the source for the krill population at South Georgia. Observations suggest that $1+(14$ to $36 \mathrm{~mm})$ and, in much higher numbers, 2+ ( 26 to $45 \mathrm{~mm}$ ) size class krill enter the South Georgia region mainly from the east (Murphy et al. 1998, Watkins et al. 1999). Krill found on the eastern end of the island are often smaller or lack the presence of older year classes, which are found on the west end of the island (Watkins et al. 1999). At the same time the biomass of krill is higher on the eastern end. The Southern ACC Front bounds the east of South Georgia (Fig. 1), which could deposit young krill on the east end of the island. This scenario is consistent with the simulated growth rates along the drifter trajectories.

However, the details of how this transport mechanism operates, especially in regard to the food sources for krill, are only now being investigated (Atkinson et al. 2001). The simulations show that subadult $(22 \mathrm{~mm})$ and larger krill (45 mm) do not grow well on planktonic food alone over the time of transport. Larval krill, however, do manage to grow utilizing planktonic food, suggesting that the food that is available is sufficient to sustain only the smaller size classes of krill.

The lack of growth of subadult and older krill during transport may result from either incorrect parameterization of krill growth processes in the model or from incorrect specification of the food sources. The first seems unlikely since the krill growth model has been tested and calibrated against a range of data sets (Hofmann \& Lascara 2000), the majority of which were obtained for subadult and older krill. The latter is the more likely cause and this can only be addressed by studies that are directed at determining potential food sources in the Scotia Sea. Thus, future studies of krill across the Scotia Sea should also include measurements of the food environment. Mesoscale features with high concentrations of pelagic phytoplankton are potentially an important mechanism for enhancing food encountered by krill as they drift across the Scotia Sea, especially for the older krill. The role of these features remains to be quantified.

An interesting result of the simulations is that the subadult and larger krill do not grow to the expected size encountered at South Georgia during the 140 to $160 \mathrm{~d}$ of transport, except when they feed on copepods in addition to phytoplankton. To grow krill to the 2+ size observed at South Georgia requires a continuous high food environment, which is not likely to occur in the Scotia Sea (Fig. 3), where phytoplankton concentrations tend to be low and copepods seem to be less abundant (Atkinson \& Sinclair 2000). However, the krill sizes around South Georgia used for comparison in this study are primarily from summer surveys. The transport scenarios proposed in this study would result in krill arriving at South Georgia in winter, which would give an additional 6 mo for the krill to grow to the observed sizes.

Another possible explanation is that krill that begin transport at the Antarctic Peninsula in austral summer overwinter under the sea ice that extends out to the Scotia Sea from the Weddell Sea (Figs. 5 \& 6 this study; Murphy et al. 1998). These krill then begin transport again the following spring when the sea ice recedes. This scenario of an interrupted transport provides the 
krill a refuge from a low food environment in the winter, presumably utilizing food associated with sea ice, and therefore an opportunity for survival during winter. The dynamics of this transport process are likely to be complex since they depend on the northward extent of the winter sea ice and the location of the Southern ACC Front and Boundary, which are potentially tied to larger scale climatic effects.

Acknowledgments. This research was supported by the US National Science Foundation, Office of Polar Programs grant number OPP 9525806. Computer facilities and resources were provided by the Commonwealth Center for Coastal Physical Oceanography at Old Dominion University. We thank A. Atkinson and 3 anonymous reviewers for constructive comments on an earlier version of this manuscript.

\section{LITERATURE CITED}

Atkinson A, Sinclair JD (2000) Zonal distribution and seasonal vertical migration of copepod assemblages in the Scotia Sea. Polar Biol 23:46-58

Atkinson A, Snÿder R (1997) Krill-copepod interactions at South Georgia, Antarctica, I. Omnivory by Euphausia superba. Mar Ecol Prog Ser 160:63-76

Atkinson A, Whitehouse MJ, Priddle J, Cripps GC, Ward P, Brandon MA (2001) South Georgia, Antarctica: a productive, cold water, pelagic ecosystem. Mar Ecol Prog Ser 216: 279-308

Balch WM, Evans R, Brown J, Feldman G, McClain C, Esaias W (1992) The remote sensing of ocean primary productivity: use of a new data compilation to test satellite algorithms. J Geophys Res 97(C2):2279-2294

Brandon MA, Murphy EJ, Whitehouse MJ, Trathan PN, Murray AWA, Bone DG, Priddle J (1999) The shelf break front to the east of the sub-Antarctic island of South Georgia. Cont Shelf Res 19:799-819

Brierley AS, Demer DA, Watkins JL, Hewitt RP (1999) Concordance of interannual fluctuations in acoustically estimated densities of Antarctic krill around South Georgia and Elephant Island: biological evidence of same-year teleconnections across the Scotia Sea. Mar Biol 134(4): 675-681

Brinton E (1985) The oceanic structure of the eastern Scotia Sea-III. Distributions of euphausiid species and their developmental stages in 1981 in relation to hydrography. Deep-Sea Res 32(10):1153-1180

Boyer T, Levitus S (1994) Quality control and processing of historical oceanographic temperature, salinity, and oxygen data. NOAA Tech Rep NESDIS 81

Buchholz F (1985) Moult and growth in Euphausiids. In: Siegfried WR, Cody PR, Laws RM (eds) Antarctic nutrient cycles and food webs. Springer Verlag, Berlin, p 339-345

Buchholz F (1991) Molt cycle and growth of Antarctic krill Euphausia superba in the laboratory. Mar Ecol Prog Ser 69:217-229

Canuto C, Hussaini MY, Quarteroni A, Zang TA (1988) Spectral methods in fluid dynamics. Springer series in computational physics. Springer Verlag, New York

Clarke A, Morris DJ (1983) Towards an energy budget for krill: the physiology and biochemistry of Euphausia superba Dana. Polar Biol 2:69-86

Comiso JC, Sullivan CW (1986) Satellite microwave observa- tions of the Weddell Sea ice cover and its marginal ice zone. J Geophys Res 91(C8):9663-9681

Comiso JC, Grenfell TC, Bell D, Lange M, Ackley S (1989) Passive microwave in situ observations of Weddell Sea ice. J Geophys Res 94(C8):10891-10905

Comiso JC, McClain CR, Sullivan CW, Ryan JP, Leonard CL (1993) Coastal Zone Color Scanner pigment concentrations in the Southern Ocean and relationships to geophysical surface features. J Geophys Res 98(C2):2419-2451

Croxall JP, McCann TS, Prince PA, Rothery R (1988) Reproductive performance of seabirds and seals at South Georgia and Signy Island, South Orkney Islands, 1976-1987: implications for Southern Ocean. In: Sahrhage D (ed) Antarctic Ocean and resource variability. Springer-Verlag, Berlin, p 261-285

Daly KL (1990) Overwintering development, growth, and feeding of larval Euphausia superba in the Antarctic marginal ice zone. Limnol Oceanogr 35(7):1564-1576

Daly KL, Macaulay MC (1991) Influence of physical and biological mesoscale dynamics on the seasonal distribution and behavior of Euphausia superba in the antarctic marginal ice zone. Mar Ecol Prog Ser 79:37-66

Everson I (1984) Marine interactions. In: Laws RM (ed) Antarctic ecology, Vol 2. Academic Press, London, p 783-819

Feldman GC, Kuring N, Ng C, Esaias W and 9 others (1989) Ocean color: availability of global data set. EOS Trans AGU 70:634-641

Gordon HR, McCluney WR (1975) Estimation of the depth of sunlight penetration in the sea for remote sensing. Appl Opt 14:413-416

Granéli E, Granéli W, Rabbani MM, Daugbjerg N, Fransz G, Cuzin-Roudy J, Alder VA (1993) The influence of copepod and krill grazing on species composition of phytoplankton communities from the Scotia-Weddell sea. Polar Biol 13: 201-213

Hofmann EE, Klinck JM, Locarnini RA, Fach BA, Murphy EJ (1998) Krill transport in the Scotia Sea and environs. Antarct Sci 10(4):406-415

Hofmann EE, Lascara CM (2000) Modeling the growth dynamics of Antarctic krill Euphausia superba. Mar Ecol Prog Ser 194:219-231

Hopkins TL, Lancraft TM, Torres JJ, Donnelly J (1993) Community structure and trophic ecology of zooplankton in the Scotia Sea marginal ice zone in winter. Deep-Sea Res Part I 40(1):81-105

Huntley ME, Nordhausen W, Lopez MDG (1994) Elemental composition, metabolic activity and growth of Antarctic krill Euphausia superba during winter. Mar Ecol Prog Ser 107:23-40

Ikeda T (1981) Metabolic activity of larval stages of Antarctic krill. Antarctic J U S 16:161-162

Ikeda T (1984a) Development of the larvae of Antarctic krill (Euphausia superba Dana) in the laboratory. J Exp Mar Biol Ecol 75:107-117

Ikeda T (1984b) Sequences in metabolic rates and elemental composition (C, N, P) during the development of Euphausia superba Dana and estimated food requirement during its life span. J Crustac Biol 4(S1):273-284

Ikeda T, Bruce T (1986) Metabolic activity and elemental composition of krill and other zooplankton from Prydz Bay, Antarctic, during early summer (November-December). Mar Biol 92:545-555

Ikeda T, Dixon P (1982) Body shrinkage as a possible overwintering mechanism of Antarctic krill (Euphausia superba Dana). Aust J Mar Freshw Res 33:71-76

Ikeda T, Kirkwood R (1989) Metabolism and body composition of two euphausiids (Euphausia superba and E. crystal- 
lorophias) collected from under the pack-ice off Enderby Land, Antarctica. Mar Biol 100:301-308

Ikeda T, Mitchell AW (1982) Oxygen uptake, ammonia excretion and phosphate excretion by krill and other Antarctic zooplankton in relation to their body size and chemical composition. Mar Biol 71:283-298

Ikeda T, Dixon P, Kirkwood R (1985) Laboratory observations of moulting, growth and maturation in Antarctic krill (Euphausia superba Dana). Polar Biol 4:1-18

Ishii H, Omori M, Maeda M, Watanabe Y (1987) Metabolic rates and elemental composition of the Antarctic krill Euphausia superba Dana. Polar Biol 7:379-382

Kawaguchi K, Matsuda O, Ishikawa S, Naito Y (1986) The overwintering strategy of Antarctic krill (Euphausia superba) under the coastal fast ice off the Ongul Island in Lutzow-Holm Bay, Antarctica. Mem Nat Inst Polar Res Tokyo (Spec Iss) 44:67-85.

Kils U (1982) Swimming behavior, swimming performance and energy balance of Antarctic krill Euphausia superba. BIOMASS Scientific Series 3:1-122

Mackintosh NA (1972) Life cycle of Antarctic krill in relation to ice and water conditions. Discov Rep 36:1-94

Marr JWS (1962) The natural history and geography of the Antarctic krill (Euphausia superba Dana). Discov Rep $32: 37-465$

Marschall HP (1988) The overwintering strategy of the Antarctic krill under the pack-ice of the Weddell Sea. Polar Biol 9:129-135

Morris DJ (1984) Filtration of Euphausia superba Dana: under-or over-estimates? J Crustac Biol 4(S1):185-197

Morris DJ, Keck A (1984) The time course of the moult cycle and growth of Euphausia superba in the laboratory. Meeresforsch 30:94-100

Murphy EJ, Trathan PN, Everson I, Parkes G, Daunt F (1997) Krill fishing in the Scotia Sea in relation to bathymetry, including the detailed distribution around South Georgia. CCAMLR Sci 4:1-17

Murphy EJ, Watkins JL, Reid K, Trathan PN and 6 others (1998) Interannual variability of the South Georgia marine ecosystem: biological and physical sources of variation in the abundance of krill. Fish Oceanogr 7(3/4):381-390

Nicol S, Stolp M, Cochran T, Geijsel P, Marshall J (1992) Growth and shrinkage of Antarctic krill Euphausia superba from the Indian Ocean sector of the Southern Ocean during summer. Mar Ecol Prog Ser 89:175-181

Nordhausen W, Huntley M, Lopez MDG (1992) RACER: carnivory by Euphausia superba during the antarctic winter. Antarctic J U S 27(5):181-183

Orsi AH, Whitworth III T, Nowlin Jr WD (1995) On the meridional extent and fronts of the Antarctic Circumpolar Current. Deep-Sea Res Part I 42:641-673

Pakhomov EA, Perissinotto R, Froneman PW, Miller DGM (1997) Energetics and feeding dynamics of Euphausia superba in the South Georgia region during summer of 1994. J Plankton Res 18:399-423

Poleck TP, Denys CJ (1982) Effect of temperature on the moulting, growth and maturation of the Antarctic krill Euphausia superba (Crustacea: Euphausiacea) under laboratory conditions. Mar Biol 70:255-265

Priddle J, Croxall JP, Everson I, Heywood RB, Murphy EJ,

Editorial responsibility: Otto Kinne (Editor),

Oldendorf/Luhe, Germany
Prince PA, Sear CB (1988) Large-scale fluctuations in distribution and abundance of krill-a discussion of possible causes. In: Sahrhage D (ed) Antarctic Ocean and resources variability. Springer Verlag, Berlin, p 169-181

Quetin LB, Ross RM (1985) Feeding by Antarctic krill Euphausia superba: does size matter? In: Siegfried WR, Condy PR, Laws RM (eds) Antarctic nutrient cycles and food webs. Springer Verlag, Berlin, p 372-377

Quetin LB, Ross RM (1989) Effects of oxygen, temperature and age on the metabolic rate of the embryos and early larval stages of the Antarctic krill Euphausia superba Dana. J Exp Mar Ecol 125:43-62

Quetin LB, Ross RM, Clarke A (1994) Krill energetics: seasonal and environmental aspects of the physiology of Euphausia superba. In: El-Sayed SZ (ed) Southern Ocean ecology: the BIOMASS perspective. Cambridge University Press, Cambridge, p 165-184

Rosenberg AA, Beddington JR, Basson M (1986) Growth and longevity of krill during the first decade of pelagic whaling. Nature 324:152-154

Ross RM, Quetin LB (1986) How productive are Antarctic krill? Bioscience 36(4):264-269

Ross RM, Quetin LB, Baker KS, Vernet M, Smith RC (2000) Growth limitation in young Euphausia superba under field conditions. Limnol Oceanogr 45(1):31-43

Schnack SB (1985) Feeding by Euphausia superba and copepod species in response to varying concentrations of phytoplankton. In: Siegfried WR, Condy PR, Laws RM (eds) Antarctic nutrient cycles and food webs. Springer Verlag, Berlin, p 311-323

Siegel V (1987) Age and growth of Antarctic Euphausiaca (Crustacea) under natural conditions. Mar Biol 96:483-495

Siegel V (1992) Assessment of the krill (Euphausia superba) spawning stock off the Antarctic Peninsula. Arch Fisch Wiss 41(2):101-130

Siegel V, Kalinowski J (1994) Krill demography and smallscale processes: a review. In: El-Sayed SZ (ed) Southern Ocean ecology, the BIOMASS perspective. Cambridge University Press, Cambridge p 145-163

Siegel V, Loeb V (1995) Recruitment of Antarctic krill Euphausia superba and possible causes for its variability. Mar Ecol Prog Ser 123:45-56

Smith SL, Schnack-Schiel SB (1990) Polar zooplankton, In: Smith WO Jr (ed) Polar oceanography. Part B. Chemistry, biology, and geology. Academic Press, San Diego, p 527-599

Sullivan CW, Arrigo KR, McClain CR, Comiso JC, Firestone J (1993) Distributions of phytoplankton blooms in the Southern Ocean. Science 262:1832-1837

Torres JJ, Childress JJ (1983) Relationship of oxygen consumption to swimming speed in Euphausia pacifica 1. Effects of temperature and pressure. Mar Biol 74:79-86

Watkins JL, Murray AWA, Daly HI (1999) Variation in the distribution of Antarctic krill Euphausia superba around South Georgia. Mar Ecol Prog Ser 188:149-160

Witek Z, Kalinowski J, Grelowski A (1988) Formation of Antarctic krill concentrations in relation to hydrodynamic processes and social behavior. In: Sahrhage D (ed) Antarctic Ocean and resources variability. Springer Verlag, Berlin, p 237-244

Submitted: November 24, 2000; Accepted: September 20, 2001 Proofs received from author(s): March 27, 2002 